\title{
Theorising Open Development through an Institutional Lens: A Study of Iranian Online Interactions
}

\author{
Magda David Hercheui ${ }^{1}$, Brian Nicholson ${ }^{2}$, and Aghil Ameripour ${ }^{2}$ \\ ${ }^{1}$ Westminster Business School, London, United Kingdom \\ m.hercheui@westminster.ac.uk \\ ${ }^{2}$ Manchester Business School, Manchester, United Kingdom \\ brian.nicholson@manchester.ac.uk, ameripour@googlemail.com
}

\begin{abstract}
Open development has been conceptualised as initiatives that use information technology to foster citizen participation and freedom of debate in development projects. The Internet has brought hope that citizens would have an opportunity to organise campaigns, thus fostering democracy. These possibilities face a number of obstacles. Analysing case evidence from Iran, this study explores how institutions have influenced the forms of appropriation of Internet tools in initiatives intended to enable open development. The paper contributes to our understanding of institutional mechanisms for controlling and constraining open development initiatives, and the relevance of institutional environments when planning open development projects.
\end{abstract}

Keywords: democracy, institutional theory, Internet, Iran, open development.

\section{Introduction}

The idea that openness is an important step towards development has been explored by academic research. In the field of development studies (social science studies on developing countries), it is proposed that democracy and political freedom are important fundamental elements for development [26]. The emergence of the Internet and other computer networks has brought a new perspective on openness. Some scholars posit that information technology may foster freedom of expression, enabling citizens to have more participation in political processes [5].

Some authors have related open development to the possibilities that emerge when open information networked activities are fostered in particular environments and societies [27]. The idea of openness in development studies is broadly related to many aspects of adopting and appropriating information technology, from having access to technology and its use to being able to reach relevant content and to participate in the creation of content. Open development refers to a set of possibilities to catalyse positive change through open information networked activities. Openness that serves the purpose of development implies that positive outcomes are expected when societies engage in a participatory way, e.g. when people have access to network technologies enabling democracy, freedom of expression, inclusion, and participation in decision 
making on matters which are relevant for them [27]. However, it is also expected that such citizen participation would impact power structures in society, fostering institutional change [2]. In such a situation, attempts to foster open development may face opposition from particular social actors who fear losing power, especially in countries in which citizen engagement and freedom of expression are suppressed.

Prior research has considered whether the Internet may foster more democratic institutions, permitting citizens to share opinions and information, and offer tools for political mobilisation [5], [8], [12], [23]. On the one hand, in some contexts, the Internet opens up spaces for public debates and citizen empowerment [10], [13], [14], [23], [29]; on the other hand, states also have instruments to control Internet interactions and to use Internet tools to increase citizen surveillance, especially in environments which do not have functional democratic institutions [1], [15], [19], [20].

State institutions influence the way Internet tools are appropriated. This has been seen when access to the Internet was curtailed to prevent the use of social media (such as YouTube, Facebook, Twitter, and Blogs) during turbulent political manifestations in Egypt and Libya in 2011, as broadly discussed by news media ${ }^{1}$ and some academic papers $^{2}$. Another example is the prosecution of activists who use the Internet to oppose political power in China ${ }^{3}$ and $\operatorname{Iran}^{4}$. This study proposes to investigate how state institutions influence the forms of appropriation of Internet tools in open development initiatives.

This research focuses on two case studies in Iran, in which citizens have used Internet tools to manifest their opinions in political debates. The first case describes the story of an Iranian news website (Alef) which questioned the nomination of a Minister of Interior in 2008. The second case explores two Iranian activist movements which rely on the Internet (websites, blogs and forums) to organise and communicate with citizens. One fights for women's equal rights (1 Million Signature Campaign), and another focuses on stopping stoning, the punishment reserved for those who are condemned to execution for adultery (Stop Stoning Forever Campaign). Both movements, studied in 2007, challenge established institutions in Iranian society.

This study reveals that there is evidence that Internet tools enable citizen empowerment; however, the Iranian state possesses legitimating and sanction mechanisms to

1 http://www.guardian.co.uk/world/2011/dec/29/arab-springcaptured-on-cameraphones ? INTCMP=SRCH ;

http: / /www. guardian.co.uk/technology/2011/jul/07/telecomixarab-spring? INTCMP $=\mathrm{SRCH}$;

http: / /www . guardian.co.uk/world/2011/dec/25/egyptian-judgefrees-blogger? INTCMP $=\mathrm{SRCH}$

2 http://www.caida.org/publications/papers/2011/ outages_censorship/outages_censorship.pdf

3 http: //cyber. law.harvard.edu/filtering/china/; http://en.wikipedia.org/wiki/Internet_censorship_in_the_ People\%27s_Republic_of_China

4 http://www.guardian.co.uk/world/2012/jan/05/iran-clampsdown-internet-use; http://en.wikipedia.org/wiki/Internet_censorship_in_Iran 
constrain this empowerment. The paper is organised as follows: the next section introduces an operational summary of institutional theory. Subsequently, the methodology used to collect data is explained. This is followed by the case description, and analysis of cases. In the final section are the conclusions.

\section{Institutional Theory}

Institutions are understood as resilient social structures that are reproduced in society. In other words, institutions may be defined as social behaviour that follows defined patterns and is diffused through settings and times [3], [25].

Supported by rules, norms, and cultural-cognitive systems, institutions are resilient: it is difficult to change established social structures [6], [25]. However, society also has a degree of freedom to change institutions, either because there are conflicts of interest between social actors or because new contexts and situations emerge [11], [16]. In any society, there are institutions which are in conflict with each other [16]. Thus, institutions may be changed at any time, when social actors act in the direction of fostering new social structures [16].

In addition to rules, norms and cultural-cognitive systems, sanction mechanisms of reward and punishment support the reproduction of institutions [11], [25]. When behaviour is institutionalised, it implies that society has the means to control it [3]. For instance, judicial systems apply judgment based on rules and control mechanisms of punishment; society disapproves and ostracises people who do not comply with norms [21]. Powerful actors keep the control of resources, which are fundamental for applying sanction mechanisms, either rewarding those who comply with the institutions or imposing punishment on those who not [18], [21].

Legitimacy is also a relevant pillar of institutions. Within a social system, when a pattern of behaviour is understood as appropriate in a given situation, society attributes legitimacy to actors that repeat such behaviour [21], [28]. Legitimacy depends on conformity to rules, norms and cognitive frames of reference [18], [21]. Social actors may comply with institutions as a way of obtaining social legitimacy, thus increasing their chances of receiving resources from society [18]. However, legitimacy is not without ambiguity: actions may be interpreted as legitimate, or not, according to different perspectives and contexts [3], [16].

\section{Methodology}

This research follows an interpretive approach to explore the meanings social actors give to their actions in particular situations [3], [9]. The approach is particularly interesting to understand the how institutions influence behaviour, and how behaviour reinforce and challenge institution. The data collection is based on semi-structured interviews (nine related to the case of activist movements) (table 1) and content analysis of the material published on the websites and blogs studied (Alef's website and 30 blogs related to both activist movements) [7], [17]. 
Interviews were limited in number because of the sensitivity of the theme: activists feared to be identified. Interviews were conducted by phone or the Internet, to protect the identity of interviewees. Because of the limited number of interviews, this research focuses mainly on incorporating content analysis of published material. The interviews have aimed to confirm details observed on websites and to explore topics that were not present in the published content.

Table 1. Details of the interviews

\begin{tabular}{|c|c|c|c|c|}
\hline Role & Gender & $\begin{array}{l}\text { Communication } \\
\text { Channel }\end{array}$ & Date & Duration \\
\hline Feminist activist & $\begin{array}{l}\text { Female } \\
\text { (assumed) }\end{array}$ & Email & $23 / 04 / 2007$ & Not applicable \\
\hline Feminist activist & $\begin{array}{l}\text { Female } \\
\text { (assumed) }\end{array}$ & Email & $14 / 07 / 2007$ & Not applicable \\
\hline Feminist activist & $\begin{array}{l}\text { Female } \\
\text { (assumed) }\end{array}$ & Email & 29/07/2007 & Not applicable \\
\hline Blogger 1 & Unknown & Email & $12 / 06 / 2007$ & Not applicable \\
\hline Blogger 2 & Unknown & Email & 01/07/2007 & Not applicable \\
\hline $\begin{array}{l}\text { An academic involved } \\
\text { in the developments of } \\
\text { the Iranian Internet }\end{array}$ & Male & Email & 05/04/2007 & Not applicable \\
\hline Mayoral candidate & Female & $\begin{array}{l}\text { Telephone } \\
\text { interview }\end{array}$ & 20/07/2007 & $\begin{array}{l}\text { Approximately } \\
40 \text { minutes }\end{array}$ \\
\hline $\begin{array}{l}\text { Senior official from the } \\
\text { Ministry of ICT, Iran }\end{array}$ & Male & $\begin{array}{l}\text { Telephone } \\
\text { interview }\end{array}$ & $11 / 04 / 2007$ & $\begin{array}{l}\text { Approximately } \\
40 \text { minutes }\end{array}$ \\
\hline $\begin{array}{l}\text { Previously jailed } \\
\text { blogger (Journalist) }\end{array}$ & Male & $\begin{array}{l}\text { Telephone } \\
\text { interview }\end{array}$ & 02/07/2007 & $\begin{array}{l}\text { Approximately } \\
40 \text { minutes }\end{array}$ \\
\hline
\end{tabular}

From these primary data (available in Farsi), the research has built constructs (in English), which in this paper are presented below as case descriptions. The descriptions are narratives (second-level constructs) which summarise both cases. They take into consideration first-level constructs from interviews and content analysis (expressions also come from contributions to websites and blogs) [24]. All second-level constructs have been confirmed from more than one source (triangulation of sources) [4]. The final descriptions have been verified against the original data, confirming that the narratives are coherent and logically consistent with both sets of data, in such a way that the parts and the whole are meaningfully connected [9], [17].

This research has confirmed the symmetry between the case and the analysis, and the theoretical coherence between the case description, the analysis and institutional theory [9], [17]. The research is limited, however, in the number of cases and the timeframe of the investigation. Longitudinal analysis and a bigger number of cases could bring light to other aspects relevant to understanding the studied cases. 


\section{Case Description}

This research is based on two case studies that show forms of Internet tools that have been appropriated by different segments of Iranian citizens towards open development. It includes people who are resident inside and outside the country, during the studied timeframe (2007-2008). The cases illustrate two sets of findings, bringing examples of open development that respect and challenge institutions.

\subsection{Open Development Respecting State Institutions}

The first case involves an Iranian news website that involved its readership in online questioning of the forged qualifications of a Minister leading eventually to his impeachment. In August 2008, the validity of the Honorary Doctorate of Law degree from Oxford University held by Ali Kordan was disputed during his confirmation hearings as the Minister of Interior. The news agency Alef (http://www.alef.ir), headed by Ahmad Tavakkoli questioned the validity of the degree and published information that the University has no record of Kordan as a $\mathrm{PhD}$ student.

In spite of the state having issued warnings to Iranian media that recommended against the reporting of this topic, Alef began a campaign by asking readers to bring evidence on the certificate's authenticity. Alef readers, mainly through anonymous contributions (the website does not ask participants to use their real names), provided evidence that refuted the legitimacy of the degree. The mobilisation against the minister then spread to wider groups of citizens (not only those related to Alef), including university student groups which demanded the removal of Kordan.

Alef's campaign encountered state countermeasures when the Prosecutor General of Tehran imposed the filtering of the website (12 ${ }^{\text {th }}$ August 2008), alleging there were multiple legal actions filed against Alef. Iranian Internet Service Providers (ISPs) complied, but not all providers were able to implement the filtering immediately. Alef responded by continuing to publish content related to Kordan and permitting members to access the website through other proxies (mirror websites such as alef.com and alef-1.ir), thus avoiding the censorship imposed. Subsequently Alef complied with the recommendation to stop publishing (19 ${ }^{\text {th }}$ August 2008) until clearance was given for the website to resume without filtering by the head of the Judiciary.

In spite of suffering sanctions on website access, Alef continued to lead the action which generated protests and petitions all around the country against Kordan and which focused on the evidence of a forged degree certificate. The campaign against Kordan gained momentum until, finally, the Iranian parliament dismissed Kordan. Table 2 summarises the development of the case.

The dismissal of Kordan appears to present a significant victory for the proponents of open development as citizens used Internet channels to share knowledge that led to the eventual removal the official. However, Alef used the Internet to challenge the nomination of an individual to an official post without challenging state institutions. The campaign was conducted against Kordan although, in challenging him, Alef risked opposing the Iranian state which had nominated and defended Kordan until his impeachment. 
Alef required legal authorisation to operate under State monitoring. It did not have the goal of confronting the state. Alef moderated all readership contributions on the Kordan issue. Each message has been approved by editors before being published online in accordance with their political perspective on appropriateness. Many of the published contributions reiterated trust in the Iranian state, and questioned Kordan instead as an individual. Thus, the campaign was not associated clearly to the opposition to the State institutions.

The Alef case is promising for the practice of open development in developing countries, but the challenge was personally focused on an individual rather than on institutions. Anonymous contributions interrogated the authenticity of the degree document, and Alef overcame filtering during the period of the campaign against Kordan. However, the website also self-censored its own content, and complied with the confirmation of its legal status in the Iranian judiciary system.

Table 2. Development of Kordan's case

\begin{tabular}{ll}
\hline Event & Date (2008) \\
\hline Parliament gives vote of confidence to Kordan & $5^{\text {th }}$ August \\
Oxford denies any record of Ali Kordan's degree & $6^{\text {th }}$ August \\
Media warned not to speculate on the case & $9^{\text {th }}$ August \\
The degree certificate published and refuted by Alef's readers & $10^{\text {th }}$ August \\
Oxford refutes the published certificate & $11^{\text {th }}$ August \\
Investigation group assigned by the Parliament & $11^{\text {th }}$ August \\
Alef is filtered & $12^{\text {th }}$ August \\
Alef imposes self-censure & $19^{\text {th }}$ August \\
Filter is removed & $6^{\text {th }}$ September \\
Kordan admits that the degree is fake & $30^{\text {th }}$ September \\
Parliament removes the minister from his role & $6^{\text {th }}$ November \\
\hline
\end{tabular}

\subsection{Open Development Challenging State Institutions}

The second case explores more radical approaches to open development. The cases of two Iranian activist movements with the express aim of mobilising support to confront the state and changing aspects of the legal framework are presented. The two campaigns rely on Internet tools to organise campaigns to fight for women's equal rights (1 Million Signature Campaign), and to stop stoning (Stop Stoning Forever Campaign). Both activist movements, studied in 2007, use Internet tools (websites, blogs and forums) to organise the campaign.

The 1 Million Signature Campaign depends mainly on Internet tools to mobilise citizens' action and distribute educational information to women. For instance, PayPal was used to raise money to finance the legal costs of a woman facing the death 
penalty for having killed a man who allegedly was trying to rape her. The feminist websites also publishes photos, news and content that are banned from Iranian media for being considered by the state as threats to the Islamic Republic.

The Stop Stoning campaign challenges the legislation which allows the death penalty for stoning for those who are condemned of adultery, a punishment prescribed by the Iranian constitution and based on Sharia Law. The campaigners do not challenge Sharia Law, but that its rules have not been followed by judges. The movement aims to ban stoning from the constitution; in the short term, the objective is stopping those convicted of adultery from being stoned. The feminist and stop stoning movements confront Iranian institutions, thereby challenging the state. Both movements oppose institutions that are pervasive and resilient in Iranian society: the discrimination of women and the punishment of adultery by stoning.

Both movements depend mainly on anonymous contributions, as contributors risk punishment. Websites and blogs linked to these campaigns are registered in other countries (they are illegal in Iran), and their content is censured in Iran.

Both movements use Internet tools to overcome the filtering imposed by the Iranian state, by using proxies (URLs that are not in the list of filtered sites, which redirect communications to correct addresses) and gateways (addresses that disguise censors, presenting content within a URL that is not filtered) to permit access to content. Furthermore, both movements observe a high degree of support among similar websites and blogs to overcome state censorship. When the state censures a URL that is related to the movements, another URL or proxy is created. The network of supporters informs others how to access the censured page, overcoming the blockage.

In spite of their efforts, both movements have had limited success in changing the Iranian institutions. Stoning is still legal, although stoning has been stopped on isolated occasions. Campaigners publish the contact details of officials and details of execution arrangements, thus activists can gather to protest and impede the stoning in the locale. The 1 Million Signature Campaign attracted only a few thousand signatures. The campaign experienced some success, however, in changes to the law on the right to maternal citizenship of children born from non-Iranian fathers.

\section{Analysis}

Drawing on institutional theory, this section analyses how state institutions influence the forms of appropriation of Internet tools in open development initiatives.

\subsection{Institutional Legitimacy}

The legitimacy of open development initiatives is an important precursor to the success of the campaigns. The Alef website is legally registered in Iran, recognised by the Iranian state. In the campaign against Kordan, Alef framed its action in accordance with the state institutional legal system. Although it published content during the initial stage of filtering, it did so understanding that no judicial order has been issued against the agency. Alef applied self-censure, interrupting activities until confirming its legal status. In addition, Alef was owned by a member of the parliament, Ahmad Tavakkoli, who 
had the political support of peers to question the validity of the degree and the appropriateness of having a minister who has allegedly faked documents.

In contrast, the campaigners in activist movements do not register their websites and blogs in the Iranian legal system, and thus do not having legal legitimacy in the country. The lack of institutional legitimacy implies access to websites and blogs requires knowledge of tactics on how to find the actual material, and many citizens avoid engaging with the websites for fear of being punished.

\subsection{Punishment Mechanisms}

The cases demonstrate how punishment mechanisms act to impede open development in numerous ways. In spite of not having a formal court order, the Iranian state filtered Alef, blocking access to its content. In the first days of the filtering, Alef maintained its activities by using proxies to reach readers. Subsequently, it stopped publishing until legal compliance was established, avoiding prosecution. ISPs could also be prosecuted if they did not comply with the legal order of filtering Alef.

In contrast, feminist and stop stoning activists maintain their anonymity and operate through URLs that were not registered in Iran. If activists in Iran are discovered, they are prosecuted and imprisoned, and run the risk of torture and even death in the country's prisons. Citizens may be punished if they are discovered reading or contributing to illegal websites and blogs. Finally, ISP owners and professionals face risks of prosecution and imprisonment if they do not comply with the filtering orders.

\subsection{Fostering Institutional Change}

Alef has been successful in proving the disputed degree was fake. The minister lost his position, which may seem like a success story for open development. However, formal institutions have not changed: the episode finished with the punishment of an individual. For instance, there are no new institutional mechanisms that request more transparency and accountability from the state on the qualifications of ministers. However, the impeachment may have influence in the future questioning of decisions regarding ministerial appointments.

The activist movements have also not been able to change the legal system during the period of analysis in 2007. However, the stop stoning campaign has been successful in creating actual obstacles to stoning. Activists announce the details of planned execution, mobilising action which has resulted in cancellations. Calling attention to specific causes emphasises voices in society with different perspectives on particular institutions which may over time support activist movements both inside and outside Iran. Even though this does not represent institutional change per se, showing that institutions are contested may be an important step for fostering change [22].

\subsection{The Role of the Internet}

Alef is a registered website that depends on having a formal URL, which is controlled by the Iranian state. Alef may publish contributions from anonymous citizens but the agency is responsible for the published content. Indeed, Alef is the gatekeeper of 
contributions that are published on the website. The readers do not have access to what people post before moderation, but to what Alef permits the audience to know about what people have posted.

For instance, during the campaign against Kordan, $25 \%$ of the contributions were not published. The diversity of opinions presented, with some readers supporting and some opposing Alef's questioning of the document, may not represent the whole spectrum of contributions. The centralised approach adopted by Alef, through moderation of contributions, permits the organisation to select the spectrum and frequency of opinions in its website. Alef depends on this centralised model to have a legal URL. The chosen centralised technological infrastructure is thus coherent with the institutional status of the news agency.

The activist movements use technology differently to build a decentralised collaborative network. Internet interfaces may be set up by many providers, mainly in other countries, to direct content to Iran. The state may force Iranian ISPs to filter specific Internet addresses and key words. However, because of the decentralised nature of activist networks, there is a cat and mouse game between state censorship and activists which are able to change URLs, use proxies and gateways to circumvent the filtering of their web interfaces, and operate in other countries. This decentralised technological infrastructure allows diverse content on activist websites. Activists are anonymous, which permits them to be stronger in their criticisms. Also activists support each other by giving links to filtered URLs. This network of bloggers keeps censured websites accessible, even when their perspectives are not the same.

There is the possibility of moderation in these platforms (each blog may have moderation). However, if one blog excludes a particular opinion, the censured person may send the same content to another network node. The fragmented design of these networks (with their decentralised content production) makes it impossible for one node to control what is available in the whole network of activists.

\section{Concluding Discussion}

This paper brings two theoretical contributions to the discussion on open development. Firstly, it shows how institutions may affect open development projects. It identifies the relevance of considering the institutional context when planning open development initiatives, since powerful social actors are able to mobilise against institutional changes which challenge social structures from which they benefit. Secondly, it illustrates different models of technology appropriation when facing state constraints to open development projects, and it contrasts centralised and decentralised structures in using technology and producing content. These arguments are explained below.

This paper shows the complex interaction between forms of appropriation of technology and the institutional environment. Internet tools per se do not define whether the appropriation fosters more democratic social structures. Internet tools offer an opportunity for intensifying citizen participation and freedom of debate. However, the state has mechanisms to limit and frame this expression of dissent through filtering and censuring Internet spaces, in association with legal and illegal punishment mechanisms (from prosecution and imprisonment, to torture and execution). 
Activist movements show that it is possible to overcome state censure through the use of technical tactics (for example, changing URLs, creating proxies, using portals, and linking decentralised groups of blogs). However this implies that activists need to have substantial technical knowledge to operate in this environment. Even more difficult, readers and contributors also need to have considerable technical knowledge to find related websites and blogs. In addition, citizens in Iran may avoid reading activist content, fearing punishment. In such a repressive institutional environment, the availability of tools and contents are not enough to engage citizens in open development initiatives, especially when they do not have knowledge of the use of Internet tools and do not understand the actual risks of engagement.

The cases also point out that a decentralised strategy of content production, and loosely coupled networks of websites and blogs, may be an interesting tactic to overcome state censure. This model is more democratic in allowing the emergence of a broader range of opinions. However, states may be efficient in generating filters and in identifying contributors and supporters. The more efficient the mechanisms for identifying users, the more difficult it is to use Internet-mediated communication as a means to organise democratic debate in non-democratic environments.

The relevance of the institutional environment can be expected to be present in other initiatives that use information technology for fostering open development. This study focuses on only two cases that explore the interaction as means of fostering freedom of expression. Other studies would be necessary to understand how the appropriation of information technology for open development is affected by institutional environments in other contexts.

This study has results which indicate the limitations of Internet tools as instruments for fostering open development. Although a certain level of freedom of debate has been reached through virtual interactions, the mobilisation of citizens through the Internet has not yet been able to change Iranian institutions substantially. This paper points out thus that the resilience of institutions should be taken into account when practitioners are planning for open development. Understanding institutions, and their related legitimating and sanction mechanisms, may help to foresee obstacles to the changing of power structures brought by open development initiatives.

\section{References}

1. Alavi, N.: We are Iran. Portobello, London (2006)

2. Avgerou, C.: Discourses on ICT and development. Information Technologies and International Development 6(3), 1-18 (2010)

3. Berger, P., Luckmann, T.: The Social Construction of Reality. Allen Lane The Penguin Press, London (1966-1967)

4. Bryman, A.: Social Research Methods, 3rd edn. Oxford University Press, Oxford (2008)

5. Castells, M.: The Internet Galaxy. Oxford University Press, Oxford (2001)

6. DiMaggio, P.J., Powell, W.W.: The Iron Cage Revisited: Institutional Isomorphism and Collective Rationality in Organizational Fields. In: Powell, W.W., DiMaggio, P.J. (eds.) The New Institutionalism in Organizational Analysis, pp. 63-82. The University of Chicago Press, Chicago (1991 (1983))

7. Esterberg, K.G.: Qualitative Methods in Social Research. McGraw-Hill, Boston (2002) 
8. Feenberg, A.: Critical Theory of Communication Technology: Introduction to the Special Section. The Information Society 25(2), 77-83 (2009)

9. Gadamer, H.: Truth and Method, 2nd edn. Sheed and Ward, London (1975 (1989))

10. Grant, W.J., Moon, B., Grant, J.B.: Digital Dialogue? Australian Politicians' use of the Social Network Tool Twitter. Australian Journal of Political Science 45(4), 579-604 (2010)

11. Jepperson, R.L.: Institutions, institutional effects and institutionalism. In: Powell, W.W., DiMaggio, P.J. (eds.) The New Institutionalism in Organizational Analysis, pp. 143-163. The University of Chicago Press, Chicago (1991)

12. Jones, S.G.: Understanding community in the information age. In: Jones, S.G. (ed.) Cybersociety: Computer-mediated Communication and Community, pp. 10-35. Sage Publications, London (1995)

13. Kahn, R., Kellner, D.: New media and internet activism: From the 'Battle of Seattle' to blogging. New Media and Society 6, 87-95 (2004)

14. Kim, Y.: The contribution of social network sites to exposure to political difference: The relationships among SNSs, online political messaging, and exposure to cross-cutting perspectives. Computers in Human Behavior 27, 971-977 (2011)

15. Klang, M.: Virtual censorship: controlling the public sphere. In: Berleur, J., Numinen, M.I., Impagliazzo, J. (eds.) Social Informatics: An Information Society for All? In Remembrance of Rob Kling. IFIP, vol. 223, pp. 185-194. Springer, Boston (2006)

16. March, J.G., Olsen, J.P.: Rediscovering Institutions: the Organizational Basis of Politics. Free Press, New York (1989)

17. Mason, J.: Qualitative Researching, 2nd edn. Sage Publications, London (2002)

18. Meyer, J.W., Rowan, B.: Institutionalised Organizations: Formal Structures and Myth and Ceremony. The American Journal of Sociology 83(2), 340-363 (1977)

19. Morozov, E.: The Net Delusion: How Not to Liberate the World. Allen Lane, London (2011)

20. Norris, P.: Digital Divide: Civic Engagement, Information Poverty, and the Internet Worldwide. Cambridge University Press, Cambridge (2001)

21. North, D.C.: Institutions, Institutional Change and Economic Performance. Cambridge University Press, Cambridge (1990)

22. Oliver, C.: The antecedents of desinstitutionalization. Organisation Studies 13(4), 563-588 (1992)

23. Rheingold, H.: The Virtual Community: Homesteading on the Electronic Frontier, rev. edn. MIT Press, Cambridge (1993 (2000))

24. Schutz, A.: Collected Papers: The Problem of Social Reality. M. Nijhoff, The Hague (1962)

25. Scott, W.R.: Institutions and Organizations, 2nd edn. Sage Publications, London (2001)

26. Sen, A.: Development as Freedom. Alfred A. Knopf, New York (1999)

27. Smith, M.L., Elder, L., Emdon, H.: Open Development: A new theory for ICT4D. Information Technology and International Development 7(1), iii-ix (2011)

28. Suchman, M.C.: Managing legitimacy: strategic and institutional approaches. Academy of Management Review 20(3), 571-610 (1995)

29. Wheeler, D.L.: Working around the state: internet use and political identity in the Arab world. In: Chadwick, A., Howard, P.N. (eds.) Routledge Handbook of Internet Politics, pp. 305-320. Routledge, London (2009) 